\title{
Ichthyofauna of Fakfak, Papua - Indonesia
}

\author{
Henderite L. Ohee ${ }^{1, *}$ \\ ${ }^{1}$ Department of Biology, Faculty of Mathematics and Natural Sciences, Cenderawasih University, \\ Papua, Indonesia
}

\begin{abstract}
Fakfak and Kumawa Mountains are located in Bomberay Peninsula, Papua, a poorly known ichthyological record and was recommended by Conservation International for field inventory. This research was conducted from 6-15 February 2021 to document freshwater fish diversity in northern and eastern Fakfak toward Bomberay District. The fish was collected from creeks, streams, and rivers. The fish collection was done once in each location, mainly using a seine net, while a gill net was used in a few sites along Ubadari River. It was done for four hours, netting in one to three locations each day. Fish abundance was described based on common $(\mathrm{C})$, occasionally $(\mathrm{O})$, dan rare $(\mathrm{R})$ scales. Freshwater fish data were descriptively identified. Twenty-two native New Guinean species belonging to 19 genera and 14 families were collected during the survey. There was no specific family dominant in the fish community. All fish recorded have widespread distribution, yet only one species has restricted distribution in the Vogelkop and Bomberay Peninsulas. One rainbowfish species was observed but not properly identified. This results as initial data of the fish community of Bomberay Peninsula, especially of Fakfak. Further research is needed to reveal the fish community from another part of the peninsula.
\end{abstract}

\section{Introduction}

New Guinea has around 400 freshwater fish species, whereas 34 species have been shared to Australia because both areas had been connected in the past [1]. About 250 freshwater fish species are distributed in Papua [2] in three of seven sub-provinces freshwater fish zoogeographic of New Guinea. The sub-provinces partly or whole areas in Papua include sub-province Northern New Guinea, Southern New Guinea, Vogelkop Peninsula, and Western Islands [1].

After 1999, two biodiverse rapid assessments, known as RAP, were held in Papua, which recorded several new species from various taxa, including freshwater fish [3, 4]. In 1998 and 1999, freshwater fish surveys were held in Raja Ampat Island and Bird's Head [5, 6]. These expeditions show that fish diversity and endemicity were high in the area, such as Wapoga River systems and Raja Ampat, mainly on rainbowfish (Melanotaeniidae). The rainbowfish is an endemic family to New Guinea and Australia [7], and Papua is known to have high diversity compared to Papua New Guinea and Australia.

\footnotetext{
* Corresponding author: hohee08@gmail.com
} 
The sub-provinces of the Bird's Head Region are divided into two peninsulas as Vogelkop and Bomberay Peninsulas. The Vogelkop Peninsula is isolated by a narrow mountain isthmus, while Bomberay Peninsula lies north and south of the intervening Bintuni Bay. Ichthyofauna of the Vogelkop Peninsula is considered a poorly unknown area, but it shows a definite affinity with the Great Southern Province [8]. [9] confirmed that the peninsulas, including Vogelkop Lowland, Vogelkop Highland, Vogelkop Anticlines, Fakfak, and Kumawa Mountains, have high diversity and endemicity of freshwater biota based on fish (Melanotaenia, Mogurnda, Allomogurnda, and Hephaestus). These areas also support the high number of species of crayfishes and aquatic insects. Based on these findings, during the Irian Jaya Biological Conservation Priority Setting Worksop [2], the area was proposed as a priority area for biodiversity research.

[9] provided analysis on the richness and endemism of freshwater biota of New Guinea, but there was no information on endemism and richness of Order Perciformes from Fakfak and Kumawa Mountains, as well as from the "neck area" of Bird's Head Region, due to lack field surveys in the areas. It is hoped this survey can provide information to fill the gap. The survey is the first freshwater fish survey in the area.

\section{Materials and methods}

The research was conducted in 14 rivers, streams, and creeks in Ubadari, Kayuni, Kaburbur, Patimburak, Rangkedak, northern Fakfak, and in Kinam and Waremu in eastern Fakfak, between 6-15 February 2021 (Figure 1, Table 1).

Fish samples were primarily collected using 3-meter length, 1.23 meters high, and less than 0.5 inches mesh size seine net for active technic. Two people handle the net at each end of the net and form "U" shape while two to three people were chasing fish toward the net or net be dragged to a specific part of streams, creeks, or tributaries with dense submerged plants or tree roots. Passive technic using gill net was applied in water with more than 1.5-meter depth. The gill net with 2-, 3- and 4-inches mesh size, 25 meters length, and 2-meter heigh were set in a certain part of river or stream and leave it. Fish samples were collected after two or three hours, and fish identification follows [8] and [10].

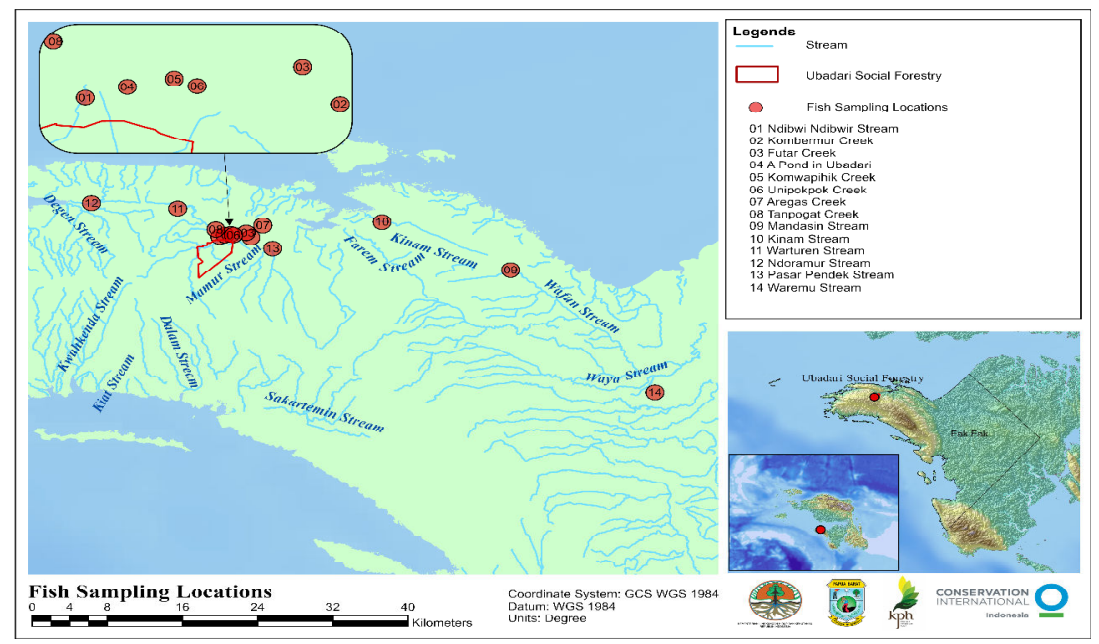

Fig. 1. Fish sampling locations in northern and eastern Fakfak, Bomberay Peninsula, Papua, Indonesia (red dot). Most of the locations were located near ocean or less than $20 \mathrm{~km}$. 
Fish collections were done four hours per day in one to three locations each day. Freshwater fish diversity was descriptively analyzed by describing the distribution and zoogeographic of the fish in New Guinea. Fish abundance was described based on common (C), occasionally $(\mathrm{O})$, and rare (R) scales [4] (Table 2). Fish diversity was grouped based on its distribution area (Table 3 ) and its family (Table 2).

Table 1. Sampling locations and their distance to sea and elevation in northern and eastern Fakfak, Papua, Indonesia.

\begin{tabular}{|c|c|c|c|c|}
\hline $\begin{array}{l}\text { Site } \\
\text { No. }\end{array}$ & Location & $\begin{array}{l}\text { Distance of } \\
\text { the sea }(\mathrm{km})\end{array}$ & Lat\&Long & $\begin{array}{c}\text { Elevation } \\
\text { (m asl) }\end{array}$ \\
\hline 1 & Ndibwi Ndibwir Stream & 7.4 & $02^{\circ} 44^{\prime} 31.4^{\prime \prime} \mathrm{S}, 132^{\circ} 20^{\prime} 54.6^{\prime \prime} \mathrm{E}$ & 10 \\
\hline 2 & Kombemur Creek & 6.4 & $02^{\circ} 44^{\prime} 35.0^{\prime \prime} \mathrm{S}, 132^{\circ} 22^{\prime} 41.3^{\prime \prime} \mathrm{E}$ & 17 \\
\hline 3 & Futar Creek & 6 & $02^{\circ} 43^{\prime} 54.4^{\prime \prime} \mathrm{S}, 132^{\circ} 22^{\prime} 6.2$." $\mathrm{E}^{2}$ & 58 \\
\hline 4 & A pond in Ubadari & 6.8 & $02^{\circ} 44^{\prime} 25.9^{\prime \prime} \mathrm{S}, 132^{\circ} 2^{\prime} 12.2^{\prime \prime} \mathrm{E}$ & 5 \\
\hline 5 & Komwapihik Creek & 6.5 & $02^{\circ} 44^{\prime} 21.9^{\prime \prime} \mathrm{S}, 132^{\circ} 2^{\prime} 31.8^{\prime \prime} \mathrm{E}$ & 1 \\
\hline 6 & Unipokpok Creek & 6.5 & $02^{\circ} 44^{\prime} 25.6^{\prime \prime} \mathrm{S}, 132^{\circ} 2^{\prime} 41.4^{\prime \prime} \mathrm{E}$ & 8 \\
\hline 7 & Aregas Creek & 3.4 & $02^{\circ} 43^{\prime} 46.3^{\prime \prime} \mathrm{S}, 132^{\circ} 23^{\prime} 22.6^{\prime \prime} \mathrm{E}$ & 11 \\
\hline 8 & Tanpogat Creek & 3.6 & $02^{\circ} 44^{\prime} 2.8^{\prime \prime} \quad \mathrm{S}, 132^{\circ} 20^{\prime} 41.2^{\prime \prime} \mathrm{E}$ & 10 \\
\hline 9 & Mandasin Stream & 4.5 & $02^{\circ} 46^{\prime} 55^{\prime \prime} \quad \mathrm{S}, 132^{\circ} 37^{\prime} 35.8^{\prime \prime} \mathrm{E}$ & 0 \\
\hline 10 & Kinam Stream & 2 & $02^{\circ} 43^{\prime} 33.5^{\prime \prime} \mathrm{S}, 132^{\circ} 30^{\prime} 13.1^{\prime \prime} \mathrm{E}$ & 36 \\
\hline 11 & Warturen Stream & 5.3 & $02^{\circ} 43^{\prime} 33.5^{\prime \prime} \mathrm{S}, 132^{\circ} 30^{\prime} 13.1^{\prime \prime} \mathrm{E}$ & 156 \\
\hline 12 & Ndoramur Stream & 5 & $02^{\circ} 42^{\prime} 11.1^{\prime \prime} \mathrm{S}, 132^{\circ} 13^{\prime} 32.8^{\prime \prime} \mathrm{E}$ & 117 \\
\hline 13 & Pasar Pendek Stream & 4.4 & $02^{\circ} 45^{\prime} 22^{\prime \prime} \mathrm{S}, 132^{\circ} 23^{\prime} 56.1^{\prime \prime} \mathrm{E}$ & 18 \\
\hline 14 & Waremu Stream & 13.8 & $02^{\circ} 55^{\prime} 30.5^{\prime \prime} \mathrm{S}, 132^{\circ} 45^{\prime} 51.7^{\prime \prime} \mathrm{E}$ & 6 \\
\hline
\end{tabular}

\section{Results}

Twenty-two native New Guinean species belong to 19 genera, and 14 families were documented during the survey. The fish community comprises native fish of New Guinea, including one endemic species to the Vogelkop and Bomberay Peninsulas, Hephaestus lineatus, and one unidentified rainbowfish species (Melanotaenia sp.). These fish are distributed in rivers, streams, and creeks of northern and eastern Fakfak, Papua. Introduced species were not recorded in the area during the survey (Table 2).

There is no dominancy family in this study area, each family was represented by single species, except for Gobiidae and Eleotridae, which represented by five and three species, respectively (Fig. 2).

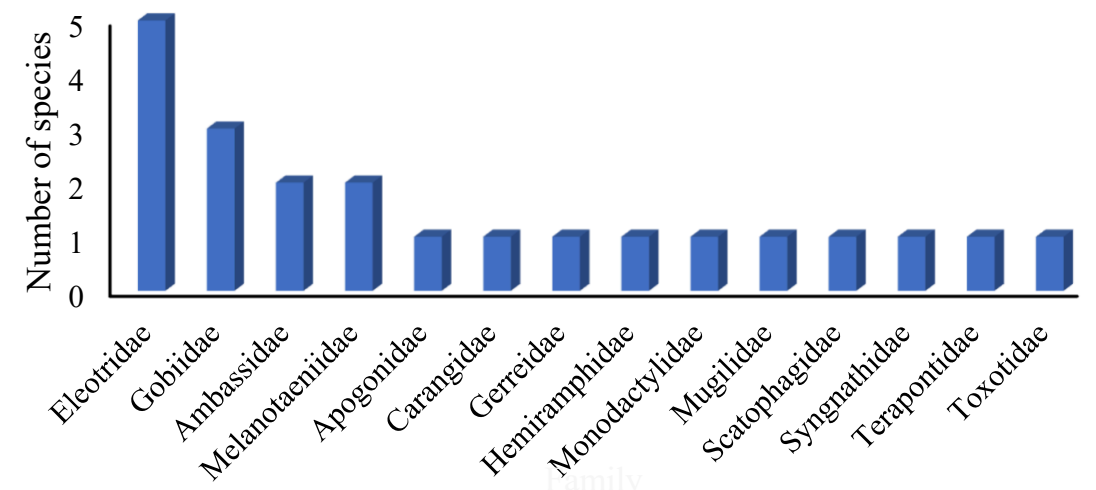

Fig. 2. Fakfak fish species composition in each family, Papua, Indonesia 
Freshwater fish abundance was grouped based on scales, including common, occasionally, and rare. Mostly, each species was observed in a single location, except Yarica hyalosoma (Mangrove cardinalfish), Scatophagus argus (Spotted scat), and Ambassis agrammus (Sailfin Glassfish), which were observed in more than one site. Many species are considered rare, but some species were observed occasionally, while one species of rainbowfish was common in some sites (Table 2).

Table 2. The freshwater fish community in Fakfak, Papua, Indonesia.

\begin{tabular}{|c|c|c|c|c|c|c|c|c|c|c|c|c|c|c|c|c|c|}
\hline \multirow[b]{2}{*}{$\begin{array}{l}\mathrm{N} \\
\mathrm{o}\end{array}$} & \multirow[b]{2}{*}{ Family } & \multirow[b]{2}{*}{ Species } & \multirow[b]{2}{*}{$\begin{array}{l}\text { Common } \\
\text { Name }\end{array}$} & \multicolumn{13}{|c|}{ Site } & \multirow[b]{2}{*}{$\begin{array}{l}1 \\
4 \\
\end{array}$} \\
\hline & & & & 1 & 2 & 3 & 4 & 5 & 6 & 7 & 8 & 9 & $\begin{array}{l}1 \\
0\end{array}$ & 11 & 1 & $\begin{array}{l}1 \\
3 \\
\end{array}$ & \\
\hline 1 & Ambassidae & A. agrammus & $\begin{array}{l}\text { Sailfin } \\
\text { Glassfish } \\
\end{array}$ & $\mathrm{O}$ & & & $\mathrm{O}$ & & & & & & & & & O & \\
\hline 2 & & A. interruptus & $\begin{array}{l}\text { Long-spinned } \\
\text { glass perchlet }\end{array}$ & & & & & & & $\mathrm{O}$ & & & & & & & \\
\hline 3 & Apogonidae & Y. hyalosoma & $\begin{array}{l}\text { Mangrove } \\
\text { cardinal fish }\end{array}$ & & $\mathrm{R}$ & & $\mathrm{R}$ & $\mathrm{R}$ & $\mathrm{O}$ & & & & & & & $\mathrm{R}$ & \\
\hline 4 & Carangidae & C. sexfasciatus & $\begin{array}{l}\text { Bigeye } \\
\text { Trevally }\end{array}$ & & & & & $\mathrm{R}$ & & & & & & & & & \\
\hline 5 & Eleotridae & H. compressa & $\begin{array}{l}\text { Empire } \\
\text { Gudgeon }\end{array}$ & $\mathrm{O}$ & & & & & & & $\mathrm{O}$ & & & & & & \\
\hline 6 & & O. fimbriata & $\begin{array}{l}\text { Fimbriate } \\
\text { Gudgeon }\end{array}$ & $\mathrm{O}$ & & & & & & & & $\mathrm{R}$ & & & $\mathrm{O}$ & & \\
\hline 7 & & G. hoedti & $\begin{array}{l}\text { False } \\
\text { Snakehead } \\
\text { Gudgeon }\end{array}$ & $\mathrm{R}$ & & & & & & & $\mathrm{R}$ & & & & & & \\
\hline 8 & & G. margaritacea & $\begin{array}{l}\text { Snakehead } \\
\text { Gudgeon }\end{array}$ & $\mathrm{R}$ & & & & & & & & & & & & & \\
\hline 9 & & B. gyrinoides & $\begin{array}{l}\text { Greenback } \\
\text { Gauvina }\end{array}$ & & & & & & & & $\mathrm{R}$ & & & & & & \\
\hline 10 & Gerreide & G. filamentosus & $\begin{array}{l}\text { Threadfin } \\
\text { Silver Body }\end{array}$ & & & & & $\mathrm{R}$ & & & & & & & & & \\
\hline 11 & Gobiidae & Glossogobius sp. 2 & Dwarf Goby & $\mathrm{C}$ & & & & & & & & & & & & & \\
\hline 12 & & S. atratus & $\begin{array}{l}\text { Black } \\
\text { stiphodon }\end{array}$ & & & & & & & & & & & $\mathrm{R}$ & $\mathrm{R}$ & & \\
\hline 13 & & S. psilosinionus & $\begin{array}{l}\text { Barcheek } \\
\text { Goby }\end{array}$ & $\mathrm{R}$ & & & & & & & $\mathrm{R}$ & & & & & & \\
\hline 14 & Hemiramphidae & Z. novaeguineae & $\begin{array}{l}\text { Fly River } \\
\text { Garfish }\end{array}$ & $\mathrm{O}$ & & & & & $\mathrm{R}$ & & & & & & & & $\mathrm{O}$ \\
\hline 15 & Melanotaeniidae & M. goldiei & $\begin{array}{l}\text { Goldie River } \\
\text { Rainbowfish }\end{array}$ & & & & & & & & & & & & & & $\mathrm{C}$ \\
\hline 16 & & Melanotaenia sp. & & & & & & & & & & $\mathrm{C}$ & $\mathrm{O}$ & & & & \\
\hline 17 & Monodactylidae & M. argenteus & Silver Moony & & & $\mathrm{R}$ & & & & & & & & & & $\mathrm{R}$ & \\
\hline 18 & Mugilidae & P. subviridis & $\begin{array}{l}\text { Greenback } \\
\text { Mullet }\end{array}$ & & & & & & & $\mathrm{R}$ & & & & & & & \\
\hline 19 & Scatophagidae & S. argus & Spotted scat & & $\mathrm{R}$ & & & $\mathrm{R}$ & & $\mathrm{O}$ & & & & & & & \\
\hline 20 & Syngnathidae & M. brachyurus & $\begin{array}{l}\text { Short-Tailed } \\
\text { Pipefish }\end{array}$ & & & & & & & & & & & & & $\mathrm{R}$ & \\
\hline 21 & Terapontidae & H.lineatus & $\begin{array}{l}\text { Lined } \\
\text { Grunter }\end{array}$ & & & & & & & & & $\mathrm{R}$ & & & & & \\
\hline 22 & Toxotidae & T. chatareus & $\begin{array}{l}\text { Seven-spot } \\
\text { Archerfish }\end{array}$ & $\mathrm{O}$ & & & & & & & & & & & & & \\
\hline
\end{tabular}

Remarks : [4]:

$\mathrm{R}=$ rare, 3 or fewer individuals per site

$\mathrm{O}=$ occasionally, $5-30$ per site

$\mathrm{C}=$ common, many per site, often more than 100

\section{Discussion}

River, streams, and creeks in Ubadari Village, Kokas area in northern and eastern Fakfak heading toward Bomberay District is mainly located inside the forest, slow to fast-flowing over boulders, rocks, and gravel bottom and located nearby sea (less than $20 \mathrm{~km}$ ). The nearest location to the sea is Kinam Stream $(2 \mathrm{~km})$. Although there was no dominancy of families, Gobiidae and Eleotridae had more species than other families during the survey. Some streams and creeks were flowing to the brackish Ubadari River, and through the mangrove 
forest. Therefore, some species recorded in this survey were marine species, such as Caranx sexfasciatus, Gerres filamentosus, Monodactylus argenteus, Planiliza subviridis, Scathopagus argus, Toxotes chatareus. Marine species and gobioid species (Gobiidae and Eleotridae) have also been discovered in the steep-gradient coastal stream habitat along coastal Cycloop, Jayapura, and streams creeks in Raja Ampat and Vogelkop Peninsula [4$6]$.

Many species were observed only in a single location during this survey, and the most common species are Yarica hyalosoma, Scatophagus argus, Ambassis agrammus, and Oxyeleotris fimbriata. These species have been recorded in some locations and are widespread throughout New Guinea [6, 8, 10, 11], except Hephaestus lineatus, which is endemic to Vogelkop and Bomberay Peninsulas.

From 11 species (52\%) distributed in Indo-West Pacific, six species (28.6\%) were distributed to South New Guinea, where Ambassis agrammus, Hypseleotris compressa, Glossogobius sp.2 were also distributed in Northern Australia. Stenogobius psilosinious (Barcheek Goby) and Zenarchopterus novaeguinea (Fly River Garfish) are restricted to Southern New Guinea. Melanotaenia goldiei (Goldiei River Rainbowfish) has also been distributed to the Aru Islands (Table 3). As part of the freshwater fish zoogeographic of New Guinea, Aru Islands were connected to Vogelkop Peninsula and Central New Guinea in the past [8].

Oxyeleotris fimbriata (Fimbriate Gudgeon) is one of few New Guinea's species distributed on both sides, Southern and Northern New Guinea, and in Bird's Head and Northern Australia. Giurus hoedti (False Snakehead Gudgeon) is distributed in both sides of New Guinea, Bird's Head and Maluku. However, it has only occurred along the coast of New Guinea [10]. Giuris hoedti is a synonym of Giuris margaritacea [11]. Ambassis interrupta ( Long-spinned glass perchlet ) distributed to Indo-Australia [10] (Table 3).

Many recent studies of Kumawa Mountain and Vogelkop Anticlines ichthyofauna have described several new species $[12,13]$. At least 4 of the 14 rainbowfish species reported are new species [14]; about 26 species of Gobiidae and Eleotridae. One blind fish living in a cave habitat is new species [15]. Expedition in 2014 has resulted in 1005 DNA vertebrate barcodes, including nine orders representing 17 families and 29 genera of fishes. The diversity of vertebrates of the Bird's Head is severely underestimated [16]. Previous studies [17-22] discovered new rainbowfish species in the area. These studies provided valuable information to our understanding of the diversity and endemism of freshwater in the Vogelkop areas and provided important information to [9]. Up to date, there is very limited information on freshwater fish available for Fakfak and surrounding areas, except rainbowfish collection done by [17] in Kokas area, about $3 \mathrm{~km}$ of Ubadari Village. He documented a new rainbowfish species, Melanotaenia kokasensis. Its distribution remains unknown and probably endemic to this area. This survey observed similar species, an unidentified rainbowfish, Melanotaenia sp., distributed near the Kokas area where M. kokasensis was discovered. Further research is necessary to confirm its species.

Table 3. Zoogeographic affinities Fakfak fish.

\begin{tabular}{lll}
\hline No & Zoogeographic affinities & Number of species (\% fauna) $(\mathrm{N}=21)$ \\
\hline 1 & Indo-West Pacific & $11(52.4 \%)$ \\
\hline 2 & South of New Guinea and Northern Australia & $3(14.3 \%)$ \\
\hline 3 & South New Guinea & $2(9.5 \%)$ \\
\hline 4 & Vogelkop and Bomberai Peninsulas & $1(4.8 \%)$ \\
\hline 5 & Indo-Australia & $1(4.8 \%)$ \\
\hline 6 & New Guinea and Northern Australia & $1(4.8 \%)$ \\
\hline 7 & New Guinea and Maluku & $1(4.8 \%)$ \\
\hline 8 & Southern New Guinea and Aru Island & $1(4.8 \%)$ \\
\hline
\end{tabular}

Source : $[8,10,3,4,11]$ 
Endemic species to Vogelkop and Bomberay Peninsulas species, Hephaestus lineatus (Lined Grunter) was observed rare and restricted in a location in the Mandasin Stream. The stream and its tributaries and other streams and creeks in the area could be the species' distribution area. Furthermore, unidentified rainbowfish species, Melanotaenia sp., was also observed $d$ in the same area, making this stream important for conservation.

Further research is needed to delineate the distribution area of Hephaestus lineatus in Fakfak and recollected the Melanotaenia sp. to confirm its species status. Fortunately, no introduced species were observed in this survey in the areas. However, it was reported an introduced species, Oreochromis mossambicus, of Bomberay River, $63 \mathrm{~km}$ of Ubadari Village [23]. Introduced species could spread quickly to other natural water and streams and threaten native species [24-26], where one of them is Lake Sentani.

\section{Conclusion}

Twenty-two native New Guinean species belong to 19 genera, and 14 families were recorded in Ubadari and surrounding villages, Fakfak. The fish species are mostly reported as widespread New Guinean species, except one species endemic to Vogelkop and Bomberay species, Hephaestus lineatus, and one unidentified rainbowfish, Melaotaenia sp. During this survey, no record of introduced species in the area. Further research is needed to add the distribution area of the endemic species and collect more specimens of the rainbowfish to confirm its species status.

\section{Acknowledgments}

The survey would not have been possible without generous financial support from Conservation International. Special thanks to the Dean of Mathematics and Natural Sciences Faculty of UNCEN for research permission. I also thank the Ubadari Village leader and the community, who help me do the fish collection.

\section{References}

1. G.R. Allen, Fishes of Papua in the ecology of Papua part one (Periplus Editions (HK) Ltd., Singapore, 2007)

2. Conservation International, The Irian Jaya biodiversity conservation priority-setting workshop final report (Conservation International, Washingon DC, 1999)

3. G. Allen, S. Renyaan, Fishes of the Wapoga River system, Northwestern Irian Jaya, Indonesia, in a biological assessment of the Wapoga River area of Northwestern Irian Jaya, Indonesia - RAP bulletin of biological assessment 14 (Conservation International, Washington DC, 2000)

4. G.R. Allen, H, Ohee, P. Boli, R. Bawole, Warpur, Fishes of the Yongsu and Dabra areas, Papua, Indonesia, in a biodiversity assessment of Yongsu - Cyclops Mountains and the Southern Mamberamo Basin, Papua, Indonesia - RAP bulletin of biological assessment 25 (Conservation International, Washington, DC, 2002)

5. G.R. Allen, S.J. Renyaan, Survey of the freshwater fishes of Irian Jaya, phase II (B) 1998, fishes of the Raja Ampat Islands (Unpublished Report, 1998)

6. G.R. Allen, S.J. Renyaan, Survey of the freshwater fishes of Irian Jaya-fishes of the Raja Ampat Islands, Misool Island, and South-Central Vogelkop Peninsula (Unplished Report, 2000) 
7. G.R. Allen, Rainbowfishes (Tetra-Verlag, Germany, 1995)

8. G.R. Allen, Field guide to the freshwater fishes of New Guinea (Christensen Research Institute, Madang, 1991)

9. D.A. Polhemus, R.A. Englund, G.R. Allen, Freshwater biotas of New Guinea and nearby Islands : analysis of endemism, richness and threats (Unpublished Report, 2004)

10. G.R. Allen, K. Hortle, S.J. Renyaan, Freshwater fishes of the Timika Region New Guinea (PT Freeport Indonesia, Timika, 2000)

11. R. Froese, D. Pauly, FishBase, www.fishbase.org (2020)

12. Kadarusman, R.K. Hadiaty, Sudarto, L. Pouyaud, Lengguru Kaimana 2010 preliminary assessment of karst biodiversity - final report (Unplished Report, 2010)

13. L. Pouyaud, G. Semiadi, Kadarusman, R. Hocde, Lengguru 2014 expedition - final report (Unplished Report, 2014)

14. R. Kadarusman, K. Hadiaty, G. Segura, G. Setiawibawa, D. Caruso, L. Pouyaud, Cybium 36, 2 (2012)

15. L. Pouyaud et al., Cybium 36, 4 (2012)

16. E. Arida et al., Mol. Ecol. Resour. 00 (2021)

17. G.R. Allen, P.J. Unmack, R.K. Hadiaty, Int. J. Ichthyol. 14, 5 (2008)

18. Kadarusman, Sudarto, E. Paradis, L. Pouyaud, Cybium 34,2 (2010)

19. G.R. Allen, R.K. Hadiaty, Fishes of Sahul 25, 1 (2011)

20. M.F.I. Nugraha et al., Cybium 39, 2 (2015)

21. G.R. Allen, P.J. Unmack, R.K. Hadiaty, Aqua. Int. J. Ichthyol. 20, 3 (2014)

22. G.R. Allen, P.J. Unmack, R.K. Hadiaty, Aqua. Int. J. Ichthyol. 22, 1 (2016)

23. Department of the Environment and Land of Fakfak Regency, Final report on the potential biodiversity survey of Fakfak Regency, West Papua Province, Fakfak, West Papua (Unpublished Report, 2018)

24. R. Tiberti, A. von Hardenberg, G. Bogliani, Hydrobiologia 724, 1 (2014)

25. J.M. Shelton, M.J. Samways, J. A. Day, Biol. Invasions 17, 1 (2015)

26. H.L. Ohee, P. Sujarta, S. Surbakti, H. Barclay, Biodiversitas 19, 6 (2018) 